\title{
PEMETAAN KEBUTUHAN PENDIDIKAN KECAKAPAN HIDUP DI KAWASAN WISATA KARST KECAMATAN PRACIMANTORO KABUPATEN WONOGIRI
}

\author{
Iis Prasetyo, Entoh Tohani dan Al. Setya Rohadi \\ Universitas Negeri Yogyakarta \\ Email: iis.prasetyo@uny.ac.id
}

\begin{abstract}
Abstrak
Penelitian ini bertujuan untuk mendeskripsikan:1) pandangan masyarakat di kawasan wisata karst terhadap pengembangan kawasan wisata karst; 2) kebutuhan pendidikan kecakapan hidup bagi masyarakat di kawasan wisata karst dalam upaya memberdayakan masyarakat; dan 3) kendala yang dihadapi dalam pengembangan kawasan wisata karst. Penelitian ini merupakan penelitian studi kasus dengan unit analisis adalah kawasan wisata karst Kecamatan Pracimantoro, Wonogiri. Pengumpulan data dilakukan dengan wawancara/FGD, dokumentasi, dan observasi. Analisis data menggunakan teknik analisis kualitatif dengan triangulasi, diskusi terfokus, dan pengamatan. Hasil penelitian menunjukkan bahwa pengembangan kawasan karst dapat meningkatkan kualitas hidup, membuka peluang pekerjaan. Pengembangan pendidikan kecakapan hidup bersentuhan dengan keberadaan kawasan karst dapat mengoptimalkan fungsinya sebagai sarana pendidikan dan wisata. Kendala yang muncul, berkaitan dengan teknis pengelolaan sumber daya manusia dan lingkungan; kurangnya koordinasi antar instansi menyebabkan pengembangan aset belum berjalan dengan baik; kurangnya kesadaran masyarakat dalam menyukseskan kegiatan pariwisata; tidak adanya pengembangan dari pihak eksternal; dan infrastruktur yang masih terbatas.
\end{abstract}

Katakunci: Kebutuhan, kecakapan hidup, kawasan karst, pendidikan

\section{MAPPING THE NEEDS OF LIFE SKILLS EDUCATION IN KARST TOURISM DISTRICT OF PRACIMANTORO, WONOGIRI}

\begin{abstract}
This study aimed to describe: 1) the views of community in the tourist area of karst on the development of the tourist area of karst; 2) need for life skills education for community in the tourist area of karst in empowering communities; and 3) the obstacles encountered in the development of the tourist area of karst. This research is a case study with the unit of analysis is the tourist area of karst Pracimantoro Subdistrict, Wonogiri. Data were collected by interview/FGD, documentation, and observation. The data analysis was performed using qualitative analysis techniques. As for the validity of the data obtained in this study triangulation, the discussion focused, and the extension of the observations will be used. The results showed that the development of karst areas can improve the quality of life, be able to open up job opportunities. The development of life skills education should be developed to optimize its function as a means of education and travel. The constraints that arise are related to the technical management, human resources and the environment, there is no coordination among related agencies led to the development, public awareness has not been proactive in ensuring the success of tourism activity, the absence of external development, and the infrastructure are still limited.
\end{abstract}

Keywords: education, life skills, karst region, needs 


\section{PENDAHULUAN}

Peningkatan kualitas hidup warga masyarakat ditentukan oleh proses pembangunan yang dilaksanakan oleh pihak terkait. Akhir-akhir ini, pembangunan diarahkan pada pemanfaatan dan pengembangan segenap potensi yang dimiliki oleh suatu wilayah yang diwujudkan dengan kegiatan pengembangan wilayah. Pengembangan wilayah dimaknai sebagai proses pembangunan yang dilakukan sesuai dengan potensi yang dimiliki, permasalahan yang dihadapi, dan kemampuan atau dukungan lain yang bersumber dari masyarakat sendiri. Pada dasarnya, pengembangan wilayah dimaknai sebagai upaya memenuhi kebutuhan hidup warga masyatakat mendasarkan pada kapasitas masyarakat atau kelompok sasaran. Terkait ini, pemerintahn Kabupaten Wonogiri sedang berusaha mengembangan wilayahnya atas dasar potensi yang dimilikinya yaitu pengembangna kawasan karst yang diharapkan menjadi kawasan wisata berbasis alam (nature based tourism).

Keberhasilan pengembangan wilayah Kabupaten Wonogiri tidak lepas dari pendayagunaan keunggulan yang dimilikinya baik mencakup keunggulan komperatif dan keunggulan kompetitif. Keunggulan komperatif dimaknai sebagai segala potensi yang dimiliki masyarakat berupa potensi alam, budaya, ekonomi, maupun potensi lainnya yang dapat dimanfaatkan untuk mencapai kesejahteraan hidup masyarakat. Potensipotensi ini menjadi modal untuk menciptakan warga masyarakat yang sejahtera baik secara material maupun nonmaterial. Salah satu keunggulan komperatif yang dimiliki Kabupaten Wonogiri adalah potensi alam bebatuan karst yang ada di hampir seluruh wilayah Wonogiri terutama di wilayah Kecamatan Pracimantoro. Kawasan ini telah mendapatkan pengakuan internasional dari Unesco sebagai salah satu kawasan karst terbaik di dunia. Oleh karenanya, pemerintah Kabupaten Wonogiri berupaya mengembangkan kawasan karst yang dimilikinya dengan pemikiran bahwa kawasan karst yang ada dapat difungsikan sebagai kawasan wisata pendidikan, konservasi lingkungan, dan pemberdayaan masyarakat. Di Indonesia, selain di kecamatan ini, terdapat banyak wilayah yang memiliki kawasan karst antara lain kawasan Bukit Barisan (Sumatera Selatan), Lebak (Banten), Sukabumi, Pangandaran, Bandung (Jawa Barat), Kalimantan Timur, Sumatera Utara, Maros-Pangkep (Sulawesi Selatan), Fakfak, dan lain-lain.

Istilah karst berasal dari bahasa preIndoeuropean yaitu karra/gara yang berarti batu. Turunan kata ini dapat ditemukan pada bahasa di Eropa dan Timur Tengah (Ford \& Williams, 2007:1). Kawasan karst merupakan tipe dataran tanah (landscape) yang dibentuk oleh pecahan batuan yang dapat larut, yang mencakup limestone dan dolomite. Kawasan karst mengandung kandungan air yang dapat menyediakan supply air yang banyak. Kawasan karst memiliki karakteristik terdapat cekungan tertutup dan atau lembah kering dalam berbagai ukuran dan bentuk, langkanya atau tidak terdapatnya drainase/sungai permukaan, dan terdapatnya goa dari sistem drainase bawah tanah (Haryono \& Tjahyo, 2015:2).

Kawasan karst memiliki berbagai potensi yang dapat dimanfaatkan dalam kehidupan, karena kawasan karst adalah sumber daya (van Beynen, 2010:1). Potensi yang ada di kawasan karst meliputi potensi sumber daya air yang banyak terkandung di dalam tanah, pontensi biotik berupa adanya keragaman hayati di kawasan ini, bahkan potensi sosial yang dapat dikembangkan (Hatma, 2006). Terkait ini, pemerintah Kabupaten Wonogiri memiliki kebijakan mengembangkan kawasan karst untuk kepentingan wisata baik untuk kepentingan ilmiah maupun kepentingan non ilmiah. Dalam kebijakannya, kawasan karst yang berada di kecamatan Pracimantoro dikembangkan sebagai wilayah yang berbasis wisata alam (ecotourism). Hasil diskusi dengan pihak pemerintah 
kabupaten Wonogiri, menunjukkan bahwa pengembangan kawasan karts masih dihadapkan masalah yang dapat menghambat keberhasilan pengembangan kawasan karst baik permasalah terkait dengan insfrastruktur, kualitas sumberdaya manusia, sinergitas maupun pendanaan. Padahal kawasan ini memiliki pontensi wisata edukasi terutama dalam mengembangkan kualitas pembelajaran (Wawancara, 08/2/2016).

Di aspek lain, keunggulan komperatif berupa kawasan karst yang dimiliki Kabupaten Wonogiri tidak dengan sendirinya memberikan manfaat yang sesuai dengan harapan. Hal ini dipengaruhi oleh kemampuan sumber daya manusia yang ada di kawasan karst, terutama warga masyarakat yang berada dan berinteraksi langsung dengan potensi dimaksud. Dalam hal ini, keunggulan komperatif tidak akan berdampak positif apabila keunggulan kompetitif wilayah tidak terbentuk. Oleh karenanya, pengembangan kualitas sumber daya manusia di kawasan karst menjadi faktor utama dalam memajukan kualitas kehidupan masyarakat.

Selain kawasan karst merupakan suatu kawasan alam yang memiliki banyak potensi, kawasan ini pun memiliki banyak masalah yang potensial terjadi. Dalam hal ini, kawasan karst sebagai ekosistem yang terkait dengan lingkungan lain dapat mengandung permasalahan seperti perusakan hutan, eksploitasi pariwisata, pencemaran air, dan lain-lain. Sebagaimana dalam gambar di bawah.

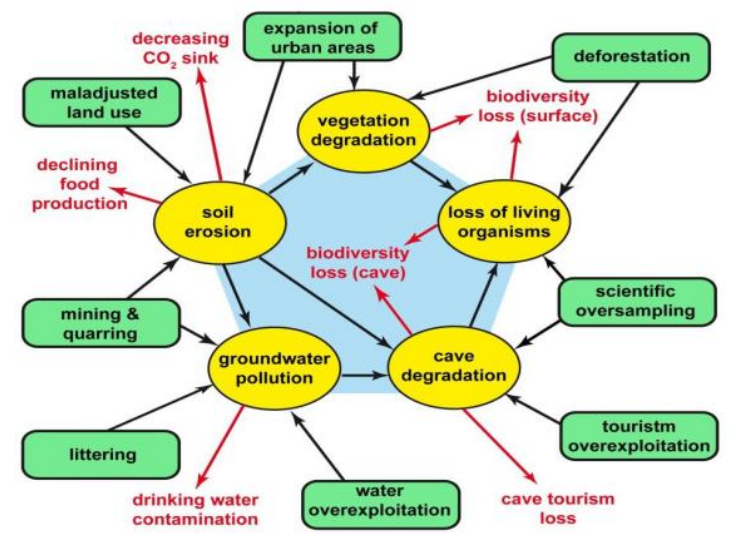

Gambar 1. Resiko Kawasan Karst (Forti, 2015)
Salah satu upaya mengembangkan keunggulan kompetitif suatu wilayah adalah dengan membekali warga masyarakatnya dengan berbagai kecakapan hidup (life skills) yang sesuai dengan lingkungannya. Dalam hal ini, warga masyarakat yang berada di kawasan karst perlu disiapkan agar mereka dapat bertindak sebagai subyek pengembangan wilayah khususnya pengembangan kawasan wisata karst. Dengan kata lain, warga masyarakat perlu memiliki kemampuan yang dibutuhkan dalam mengelola potensi yang ada di lingkungan sekitarnya. Kemampuan dimaksud mencakup berbagai kecakapan hidup (life skills) yang sesuai dengan program atau kegiatan pengembangan kawasan karst dalam memanfaatkan berbagai potensi sehingga terwujud masyarakat kreatif dan produktif. Adanya kecakapan hidup yang dimiliki oleh masyarakat di kawasan karst akan menjadi gambaran bahwa warga masyarakat mampu mengenali pontensi, masalah, dan mampu mengembangkan masalah yang dihadapinya baik terkait dengan peningkatan kualitas ekonomi, kehidupan sosial, dan perilaku berpolitik yang partisipasi.

Dalam kenyataannya, warga masyarakat di kawasan karst belum memiliki kecakapan hidup yang optimal untuk mendukung pengembangan kawasan karst sebagai wisata edukasi. Hal ini ditandai dengan belum optimalnnya fungsi kelompok sadar wisata yang berbasis pada pontensi dan sumber daya manusia lokal yang mampu mengembangkan aktivitas di kawasan wisata karst, minimnya aktivitas ekonomi produktif yang dikembangkan oleh warga masyarakat di kawasan ini, belum terbangun kesadaran dan partisipasi optimal dari warga masyarakat dalam mengembangkan kawasan karst, dan masih kecil keterlibatan masyarakat lokal dalam mengembangkan kawasan karst.

Broling menyatakan bahwa kecakapan hidup dapat mencakup: kecakapan hidup sehari-hari (daily living skill) seperti pengelolaan kebutuhan pribadi, pengelolaan keuangan pribadi, dan 
pengelolaan waktu luang dan rekreasi, kecakapan hidup pribadi/sosial (personal/social skill) seperti kesadaran diri, percaya diri, tenggang rasa pada sesama dan mengembangkan kebiasaan positif, dan kecakapan hidup bekerja (occupational skill) seperti kecakpan memilih pekerjaan, perencanaan kerja, persiapan keterampilan kerja, penguasaan kompetensi kerja dan penerapan teknologi (Anwar, 2004:56).

Menurut Sumarno (2002:16) tujuan program pendidikan kecakapan hidup dapat ditinjau dari dua perpekstif yaitu dari kualitas individu dan kualitas agregatif. Pada perspektif kualitas individu berarti program pendidikan kecakapan hidup mampu menjadikan setiap peserta didik memiliki keterampilan yang dibutuhkan oleh dirinya dan masyarakatnya. Sedangkan perspektif agregatif berarti keluaran pendidikan kecakapan hidup dituntuk memiliki komposisi keahlian yang sesuai dengan arah perubahan lingkungan masyarakatnya.

Mendasarkan pada pemikiran di atas, penelitian ini dipandang perlu dilakukan untuk mengetahui kebutuhan-kebutuhan pendidikan kecakapan hidup yang obyektif sebagai dasar pengembangan program pendidikan yang akuntabel bagi warga masyarakat yang berada di kawasan wisata karst di Kabupaten Wonogiri dalam rangka memberdayakan warga masyarakat.

\section{METODE PENELITIAN Jenis Penelitian}

Penelitian ini merupakan penelitian kualitatif dengan model studi kasus yang berusaha menjawab pertanyaan "bagaimana" dan "mengapa" dari suatu/kejadian dalam konteks tertentu. Penelitian ini berusaha memahami aktivitas sosial atau orang baik individu atau kelompok.

\section{Subyek Penelitian}

Penelitian ini dilakukan di kawasan wisata karst yang berada Kecamatan Pracimantoro, Kabupaten Wonogiri. Adapun informasi diperoleh dari subyek penelitian yang menjadi informan yang meliputi: para pengelola kelompok sadar wisata (Pokdarwis), tokoh masyarakat, tokoh pemuda, dan pihak pemerintahan yang terkait dengan pengembangan kawasan wisata karst. Informan akan dipilih secara purposif dengan pertimbangan mereka terlibat atau mengetahui aktivitas pengembangan kawasan wisata karst.

\section{Teknik Pengumpulan Data}

Pengumpulan datadilakukan dengan menggunakan teknik wawancara, observasi, dokumentasi. Wawancara baik wawancara dengan informan secara individual maupun dalam bentuk FGD akan dilengkapi dengan pedoman wawancara. Observasi akan dilengkapi dengan pedoman observasi. Sedangkan dokumentasi dilengkapi dengan pedoman dokumentasi.

\section{Teknik Analisis Data}

Setelah data terkumpul, data kualitatif yang diperoleh dianalisis dengan menggunakan teknik analisis kualitatif model interaktif (Miles \& Huberman, 2007:45). Langkah-langkah dalam menganalisis data meliputi: pertama,mengolah dan mempersiapkan data; kedua, membaca keseluruhan data, menulis catatan-catatan khusus atau gagasan-gagasan umum tentang data yang diperoleh; ketiga, mengalisis lebih detail dengan meng-coding data; keempat, menerapkan proses coding untuk mendeskripsikan setting, kategori-kategori dan tema-tema yang akan dianalisis; kelima, menunjukkan bagaimana deskripsi dan tema disajikan dalam narasi/laporan kualitatif; dan terakhir yakni menginterpretasi atau memaknai data.

\section{Keabsahan Data}

Untuk memperoleh data yang valid, teknik triangulasi, perpanjangan pengamatan dan diskusi terfokus dilakukan. Triangulasi dilakukan untuk mengecek keabsahan data yang terkumpul. 
HASIL DAN PEMBAHASAN

\section{Pandangan Masyarakat terhadap Pengembangan Kawasan Wisata Karst sebagai Objek Wisata}

Pengembangan masyarakat di kawasan wisata karst dapat dilakukan dengan menggunakan berbagai potensi yang ada. Salah satu potensi yang sangat menentukan keberhasilan pengembangan masyarakat adalah kualitas sumber daya manusia yang ada di dalamnya. SDM yang memiliki kemampuan baik akan mempermudah pencapaian tujuan pengembangan masyarakat, sebaliknya SDM yang kurang bermutu akan menyebabkan pencapaian tujuan menjadi terkendala bahkan dapat mengalami kegagalan. Oleh karenanya, pengembangan sumber daya manusia yang terlibat langsung dalam pengembangan kawasan wisata karst menjadi suatu kebutuhan.

Pendidikan nonformal dalam hal ini pendidikan kecakapan hidup dipandang dapat menjadi solusi untuk mengembangkan sumber daya manusia dimaksud, terutama warga masyarakat yang ada dan mendapat dampak langsung dari pengembangan kawasan wisata. Melalui pendidikan kecakapan hidup, sumber daya manusia dapat dikembangkan mengacu pada tujuan pengembangan kawasan wisata karst. Diharapkan warga masyarakat dapat memiliki sikap, pengetahuan, dan keterampilan yang dapat digunakan untuk mengoptimalkan peluang yang ada di lingkungan sekitar sehingga mereka dapat tetap mampu beradaptasi dan melakukan perubahan positif dalam rangka memajukan diri dan masyarakatnya.

Terkait dengan hal di atas, hasil penelitian menunjukkan bahwa pengembangan kawasan wisata karst dilakukan dengan kurang berfokus pada penyiapan sumber daya manusias di lingkungan tersebut. Pengembangan kawasan karst lebih cenderung diinisiatif oleh pemerintah sebagai pelaku utama pengembangan kawasan karst. Warga masyarakat yang berada di kawasan ini cenderung menjadi penonton atau individu yang pasif terhadap pengembangan kawasan wisata. Hal ini ditandai dengan pendidikan kecakapan hidup yang diperuntukkan guna penyiapan manusia yang siap dan mampu berkontribusi terhadap pengembangan kawasan karst masih kurang diselenggarakkan oleh pihak pemerintah. Sedikit sekali penyelenggaraan pendidikan kecakapan hidup yang berbasis pada pengembangan kawasan karst, yaitu hanya pelatihan kelompok sadar wisata (Pokdarwis) dan pelatihan kuliner bagi ibu-ibu yang pernak diselenggarakan. Namun, pelatihanpelatihan dimaksud diselenggarakan dalam waktu singkat dan tidak ada keberlanjutnya sehingga dapat dikatakan manfaat dari penyelenggaraan pendidikan kecakapan hidup tersebut tidak dapat tercapai.

Pendidikan kecakapan hidup yang bermakna adalah proses pendidikan yang mampu memberdayakan kelompok sasaran yaitu mereka yang dapat mengenali masalah dan potensi, mengetahui bagaimana solusi yang dihadapi, dan mampu melaksanakan pemecahan masalah atas dasar kemandirian dan prakarsa sendiri. Oleh karenanya, suatu proses pemahaman yang komprehensif mengenai penyelenggaraan pendidikan kecakapan hidup yang sesuai dengan konteks pengembangan kawasan wisata karst.

Pelaksanaan program pendidikan kecakapan hidup harus dilakukan dengan pengelolaan yang tepat baik perencanaan, pengelolaan dan evaluasinya (Sumarno, 2002:17). Pada tataran pembelajaran, ciri pempelajarankecakapan hidup adalah (1) terjadinya proses identifikasi kebutuhan belajar, (2) terjadinya proses penyadaran untuk belajar bersama, (3) terjadinya keselarasan kegiatan belajar untuk mengembangkan diri, belajar, usaha mandiri, usaha bersama, (4) terjadinya proses penguasaan kecakapan personal, sosial, vokasional, akademik, manajerial, kewirausahaan, (5) terjadinya proses pemberian pengalaman dalam melakukan pekerjaan dengan benar, menghasilkan produk bermutu, (6) terjadinya proses interaksi saling belajar dari ahli, (7) 
terjadinya proses penilaian kompetensi, dan (8) terjadinya pendampingan teknis untuk bekerja dan membentuk usaha bersama (Depdiknas, 2003:89).

\section{Kebutuhan Pendidikan Kecakapan Hidup di Kawasan Karst}

Pendidikan nonformal dalam hal ini pendidikan kecakapan hidup dipandang dapat menjadi solusi untuk mengembangkan sumber daya manusia dimaksud, terutama warga masyarakat yang ada dan mendapat dampak langsung dari pengembangan kawasan wisata. Melalui pendidikan kecakapan hidup, sumber daya manusia dapat dikembangkan mengacu pada tujuan pengembangan kawasan wisata karst. Diharapkan warga masyarakat dapat memiliki sikap, pengetahuan, dan keterampilan yang dapat digunakan untuk mengoptimalkan peluang yang ada di lingkungan sekitar sehingga mereka dapat tetap mampu beradaptasi dan melakukan perubahan positif dalam rangka memajukan diri dan masyarakatnya.

Hasil penelitian menunjukkan bahwa kebutuhan pendidikan kecakapan hidup diperoleh atau dikenali, mendasarkan pandangan warga masyarakat di kawasan wisata karst, adalah mayoritas kebutuhan pendidikan yang lebih mengarah pada pendidikan kecakapan hidup vokasional (vocational skills), dan hanya sedikit yang diarahkan pada pengembangan skills lainnya misal komunikasi dan hubungan dengan orang lain. Kebutuhan pendidikan tersebut didasarkan karena adanya berbagai potensi berupa sumber daya alam yang dapat dioptimalkan. Hal ini dapat dimaklumi karena masyarakat yang berada di kawasan wisata karst masih dihadapkan pada kebutuhan peningkatan kesejahteraan ekonomi.

Hal lain adalah penyelenggaraan pendidikan kecakapan hidup harus memperhatikan keberlanjutan. Artinya pendidikan kecakapan hidup harus dapat mencapai menghasilkan perubahan yang berarti pada kelompok sasaran. Dalam hal ini, pendidikan kecakapan hidup harus mampu menyiapkan warga masyarakat yang mampu mengelola aktivitas pemberdayaan (kepariwisataan) dan mampu merasakan manfaat yang langsung diperolehnya. Sifat kontinuitas pendidikan kecakapan hidup baik dari segi pengelolaan, manfaat, dan cakupan harus dapat terjamin. Akhirnya, adanya kontinuitas ini memungkinkan terjadi pengembangan kawasan wisata karst yang melibatkan segala aspek (holistik) dan integratif dan tentu mendasarkan kepada partisipasi semua pihak.

Individu diharapkan dengan kecakapan hidup mampu berinteraksi dalam cara-cara secara sehat, memiliki keinginan untuk bertindak dengan benar, dan memiliki cakupan dan kesempatan untuk melakukannya. Secara lebih rinci, WHO menjelaskan bahwa kecakapan hidup inti yang perlu dimiliki individu adalah: decision making, problem solving, creative thinking, critical thinking, effective communication, interpersonal relationship skills, self awareness, empathy, coping with emotion, dan coping with stress. Kecakapan hidup dimaksud disadari sebagai salah satu faktor yang memungkinan seseorang bertindak produkti, di mana faktor lain adalah pengetahuan, sikap, dan nilai positif yang dimiliki seseorang dan penguatan untuk berusaha. Apabila ketiganya dimiliki ia akan memudah melakukan peran dan fungsinya secara efektif.

Pendapat lain mengenai kecakapan hidup berasal dari kalangan akademisi Iowa yang mengembangkan model kecakapan hidup terutama bagi kaum pemuda di Amerika Serikat. Model life skills ini dinamanakan model 4-H life skills yaitu: hands, head, heart, dan health. Model ini dipandang cukup integratif dan detail dalam menggambarkan kecakapan hidup apa yang harus dimiliki individu.

\section{Kendala yang dihadapi dalam Upaya Pengembangan Kawasan Wisata Karst}

Penyelenggaran kegiatan pariwisata tidak lepas dari kendala yang dihadapi baik dari aspek teknis pengelolaan, sumberdaya manusia, maupun lingkungan sekitar yang 
berakibat pada pencapaian hasil tidak dapat optimal bahkan dapat menyebabkan kegagalan. Terkait ini, dalam konteks pengembangan kawasan wisata karst, ditemukan beberapa kendala antara lain: pertama, kurang koordinasi yang baik antara pengelola Museum Karst Indonesia (Badan Geologi) dan pemerintah daerah. Kebijakan pengembangan museum cenderung dilakukan oleh pihak Badan Geologi, sedangkan kebijakan pengembangan kawasan wisata karst menjadi kewenangan ditangan pemerintah daerah (dinas Pariwisata) dan pemerintah setempat. Hal ini dikemukakan oleh pengelola museum bahwa sampat saat ini belum ada koordinasi resmi dengan masyakat dan pemerintah setempat. Koordinasi yang dimaksud terkait dengan pembiayaan pengelolan museum, pengembangan sumber daya manusia, dan pengembangan wilayah kawasan karst.

Kedua, kesadaran warga masyarakat sekitar yang berpengaruh pada optimalisasi sumber daya alam dan sosial di kawasan karst. Pandangan pengelola museum menyatakan bahwa masyarakat sekitar kawasan nampaknya masih kurang proaktif dalam menyukseskan kegiatan pariwisata. Pihak museum sudah menyediakan fasilitas untuk berdagang di sepanjang jalan masuk ke museum berupa warung. Namun, praktiknya tidak banyak warga masyarakat yang memanfaatkan sarana tersebut hingga nampak akhir-akhir ini fasilitas tersebut mengalami kerusakan. Hal ini sadari bahwa warga masyarakat belum memahami bagaimana memanfaatkan peluang yang ada di kawasan wisata karst.

Ketiga, kurang pengembangan dari pihak eksternal yang memiliki kemampuan dalam mengelola kawasan wisata karst. Pihak eksternal yang dimaksud adalah mereka yang dapat memberikan inovasi pada pengembangan kawasan wisata karst. Sampai saat ini, pihak seperti komunitas pecinta wisata, agent wisata, dan lainnya belum ikut serta memberikan andil dengan memfasilitasi pada pengembangan kegiatan kepariwisataan.

\section{KESIMPULAN}

1. Pandangan masyarakat yang terutama terlibat langsung dalam pengembangan kawasan wisata karst memandang bahwa keberadaan kawasan karst penting untuk meningkatkan kualitas kehidupan. Hal ini nampak dari persepsi masyarakat bahwa adanya pengembangan kawasan karst dapat membuka peluang pekerjaan warga masyarakat sekitar museum karst Indonesia walau belum banyak yang terlibat sehingga dampak positif belum dicapai pada skala luas.

2. Pendidikan kecakapan hidup yang dapat diselenggarakan dalam upaya menyiapkan dan mengembangkan sumber daya manusia yang kompetensi untuk mengoptimalkan keberfungsian keberadaan pengembangan kawasan karst lebih berorientasi pada kecakapan hidup yang langsung bersentuhan dengan pengembangan kepariwisataan di kawasan karst yaitu pendididikan kecakapan hidup terkait dengan pengolalaan sumber daya alam lokal, pembuatan handycraft berbasis potensi lokal, peningkatan kemampuan pemasaran, pengembangkan kemampuan pengelolaan kelompok sadar wisata, dan peningkatan kemampuan soft skills warga masyarakat. Pendidikan kecakapan hidup tersebut dilaksanakan secara berkelanjutan dan berorientasi kebermaknaan.

3. Kendala yang dihadapi dalam upaya pengembangan kawasan wisata karst antara lain: kendala pengelolaan areal wisata, kualitas sumber daya manusia, dukungan masyarakat yang masih lemah, peran lembaga eksternal untuk turut serta membangun kawasan wisata karst juga masih lemah, koordinasi antar instansi yang terkait belum terlalu baik, dan terakhir adalah fasilitas infrastruktur penunjang yang masih sangat terbatas baik itu akses jalan, penerangan, transportasi dan fasilitas lainnya untuk mengunjung. 


\section{DAFTAR PUSTAKA}

Anwar. (2004). Pendidikan Kecakapan Hidup. Bandung: Aphabeta.

Depdiknas. (2003). Kecakapan Hiduppendidikan Kecakapan Hidup. Jakarta: Depdiknas.

Haryono, E \& Tjahyo, N.A. (2015). Geomorfologi dan Hidrologi Karst. Bahan ajar Fakultas Geografi, UGM. Diakses dari www.referensi.dosen.narotama.ac.id , tanggal 25 Maret 2016.

Ford, D \& Williams, P. (2007). Karst Hydrogeology and Geomorphology. West Sussex: John Wiley \& Sons Ltd.

Van Beynen, P. E. (2010). Karts Manajemen. Florida: Springer.

Hatma, S. (2006). Strategi Pengelolaan Ekosistem Karst di Kabupaten Gunung Kidul. Makalah disampaikan pada Seminar Nasional Strategi Rehabilitas Kawasan Konservasi di Daerah Padat Penduduk, 9 Februari 2006, di UGM Yogyakarta.

Forti, P. (2015). The Scientific and Socioeconomic Importance of Karst and Caves and Their Vulnerability. Diakses dari www.sustainabledevelopment.un.or g.content tanggal 25 Maret 2016.

Miles, M. B., \& Huberman, A. M. (2007). Analisis Data Kualitatif. (Terjemahan Tjetjep Rohendi Rohindi). Jakarta: Penerbit Universitas Indonesia.

Sumarno. (2002). Konsep Dasar Pendidikan Kecakapan Hidup. Jurnal Dinamika Pendidikan No.2/TH IX. November 2002. 